\title{
BIOMASS ASH AND CATTLE SLURRY MIXTURE SOLID FRACTION EXTRACTING AND ITS USE IN AGRICULTURE
}

\author{
Aivars Aboltins $^{1}$, Janis Palabinskis ${ }^{1}$, Oskars Karps ${ }^{2}$, Egle Jotautiene ${ }^{3}$ \\ ${ }^{1}$ Latvia University of Life Sciences and Technologies, Latvia; ${ }^{2}$ Institute of Agricultural \\ Resources and Economics, Latvia; ${ }^{3}$ Vytautas Magnus University, Lithuania \\ aivars.aboltins@1lu.lv, janis.palabinskis@1lu.lv,egle.jotautiene@vdu.lt
}

\begin{abstract}
As the use of local biofuels (wood and peat) in bioenergy production increases, the amount of ash as industrial waste increases. The use of wood ash from large furnaces is a technologically complex, time consuming and expensive process. The methods used to bury ashes by landfilling are unsustainable and expensive. A sustainable solution that reduces pollution is needed, as pure wood ash is a valuable source of plant food. Ash contains macro and trace elements that are needed by plants and can partially replace mineral fertilizers in agriculture, especially organic ones. The use of ash in agriculture has been little studied and implemented, the use of technology has not been resolved (ash collection and screening, fractionation, drilling, evaluation, etc.). The paper investigates the problem of mixing ash and slurry, so that the prepared ash can be spread with mechanized spreaders. Beef slurry is used as a binder to help create solid ash fractions. Studies have been carried out on the use of the obtained mixture in cultivation of summer wheat "Robbie" at different dose rates from 2-10 $\mathrm{t} \cdot \mathrm{ha}^{-1}$. The results showed that in order to return a field with a soil $\mathrm{pH}$ of 3-4 units to production at least $6 \mathrm{t} \cdot \mathrm{ha}^{-1}$ of the obtained mixture are needed. After grain cleaning, an increase in the grain weight was observed for wheat fertilized with ash-liquid manure mixture. Compared to fertilized wheat, it ranged from 10 to $18 \%$, as well as an increase in TGM of 0.44 to $2.66 \%$.
\end{abstract}

Keywords: wood ash, solid fraction, slurry, grain crops.

\section{Introduction}

Interest in using biomass for energy has grown year to year, because biomass is one form of renewable energy. Biofuels have become increasingly important worldwide as an alternative to fossil fuels. Most of households and coal-fired power plants start to use firewood or sawdust and scrap wood from wood industry and forestry. Due to the increased use of forest fuels the production of wood ash is increasing. Much of this ash is today considered as waste and is deposited in landfills at a considerable cost.

The European Green Deal tells "EU industry needs 'climate and resource frontrunners' to develop the first commercial applications of breakthrough technologies in key industrial sectors by 2030 . Priority areas include clean hydrogen, fuel cells and other alternative fuels, energy storage, and carbon capture, storage and utilisation.

A sustainable product policy also has the potential to reduce waste significantly. Where waste cannot be avoided, its economic value must be recovered and its impact on the environment and on climate change avoided or minimised" [1].

The European Commission adopted an ambitious Circular Economy Package, which includes revised legislative proposals on waste to stimulate Europe's transition towards a circular economy, which will boost global competitiveness, foster sustainable economic growth. The revised legislative proposal on waste sets clear targets for reduction of waste and establishes an ambitious and credible long-term path for waste management and recycling. This Package prompts of economic instruments to discourage landfilling [2].

Wood ash is solid residual after incineration of wood, it consists of the inorganic substances of wood. Typical elements in wood ash are calcium $(\mathrm{Ca})$, potassium $(\mathrm{K})$, silicon $(\mathrm{Si})$, phosphorus $(\mathrm{P})$, manganese $(\mathrm{Mn})$, iron $(\mathrm{Fe})$, zinc $(\mathrm{Zn})$, sodium $(\mathrm{Na})$, and etc. $[3 ; 4]$. Trace elements found in ash include arsenic (As), silver ( $\mathrm{Ag})$, molybdenum (Mo), mercury $(\mathrm{Hg})$, nickel $(\mathrm{Ni})$, cadmium $(\mathrm{Cd})$, and etc [4] The most common element in wood ash is calcium and potassium being the second most common. Ash contains generally very low nitrogen $(\mathrm{N})$, because it is vaporised during combustion.

As the consumption of biofuels increases, the amount of ash increases and much of this ash is today considered as waste and is deposited on landfills at a considerable cost. Possibilities of using ashes in different branches of economy have been rather widely studied worldwide in recent years $[5 ; 6]$. To obtain a more suitable utilization of biomass fuel, the ash as result of combustion of biofuels 
can be recycled back to the soil. The ecological and biological effects of wood ash recycling are one of the main and important objectives of scientific research.

Much attention is paid to the use of wood ash in the forest. It is a possible way to close the nutrient cycle and counteract increased soil acidity. Many scientists are studying the effects of ash on forest soil and different species in the wood [7-10].

With the increase of construction capacities and tasks, the field of application of concrete and mortar is expanding. As the amount of $\mathrm{CaO}$ in ash varies from $4 \%$ to $70 \%$, it is possible as additives or even substitutes in the production or application stages of the cement industry. Studies are provided to investigate the physical properties of various wood ash and the possible potential applications of wood ash in cement-based building materials [11-15].

Biomass ash can be used as an additive not only to cement. It can be used as an additive to increase the concentration of free ammonia in biogas slurry [16]. Studies are underway on the impact of biomass ash on the composting process of the separated organic fraction of municipal waste and the quality of the final product [17].

Wood ash can be used not only in forest soils. These by-products can be applied to agricultural soils as an organic amendment and/or a liming agent to improve the soil quality [18;19]. Farmers choose wood ash to raise the soil $\mathrm{pH}$, improve the soil fertility and thus increase the yields. Ash produced by burning wood generally has a $\mathrm{pH}$ between 9 and 13. Calculations show that completely burnt ash may have the acid-buffering capacity equal to 50-70\% of that of pure limestone [20].

Wood ash has a liming effect and can increase plant growth by up to $45 \%$ compared to traditional liming agents [21-23].

Application of wood ash in the field is difficult, because ash contains a lot of flying fractions. It could be applied with conventional lime or manure spreading equipment. Therefore, the possible granulation and solubility of granules are studied [24;25].

The present paper is dedicated to granulation of wood ash using liquid manure and the first year field experimental results. To evaluate the effect of the grainy, solid fraction of biomass ash and cattle liquid manure mixture on the yield and quality of summer wheat.

\section{Materials and methods}

The mixture of biomass ash and cattle slurry required for the field trials was prepared at the Stende Research Center at the Institute of Agricultural Resources and Economics [4].

Liquid manure was obtained from the farm "Mezchapuli", but the ash from the wood processing company "Vika Wood". Previous studies [4] have shown that ash and slurry do not contain hazardous substances. Samples were taken in 2016 and 2017. Chemical composition analyzes were performed at the Laboratory of Grain Technology and Agrochemistry at the Stende Research Center.

The ash was taken from the landfill and sifted. The manure was taken from the lagoon by mixing it beforehand. The chemical composition of the slurry was determined for its dry matter by previously removing water. A drum mixer was used to prepare the solid fraction of ash and slurry (Fig.1) and granules were dried for six days at room temperature $20^{\circ} \mathrm{C}$.

The experiments were performed in 16 plots $(10 \mathrm{~m} \times 2 \mathrm{~m})$ placed in 4 beds (Table 1). Soil characteristics- $\mathrm{pH} 5.5$, organic matter content $2.03 \%, \mathrm{~K}_{2} \mathrm{O} 101 \mathrm{mg} \cdot \mathrm{kg}^{-1}, \mathrm{P}_{2} \mathrm{O}_{5} 143 \mathrm{mg} \cdot \mathrm{kg}^{-1}$

Fertilizers for experimental sample plots

Table 1

\begin{tabular}{|c|c|}
\hline Number of beds & Fertilizer \\
\hline A1 & Mixture of ash and slurry $10 \mathrm{t} \cdot \mathrm{ha}^{-1}$ \\
\hline A2 & Mixture of ash and slurry $8 \mathrm{t} \cdot \mathrm{ha}^{-1}$ \\
\hline A3 & Mixture of ash and slurry $6 \mathrm{t} \cdot \mathrm{ha}^{-1}$ \\
\hline A4 & Control NPK $0.6 \mathrm{t} \cdot \mathrm{ha}^{-1}+\mathrm{N} 0.2 \mathrm{t} \cdot \mathrm{ha}^{-1}$ \\
\hline
\end{tabular}

Summer wheat variety "Robijs" was taken for the field trials. 


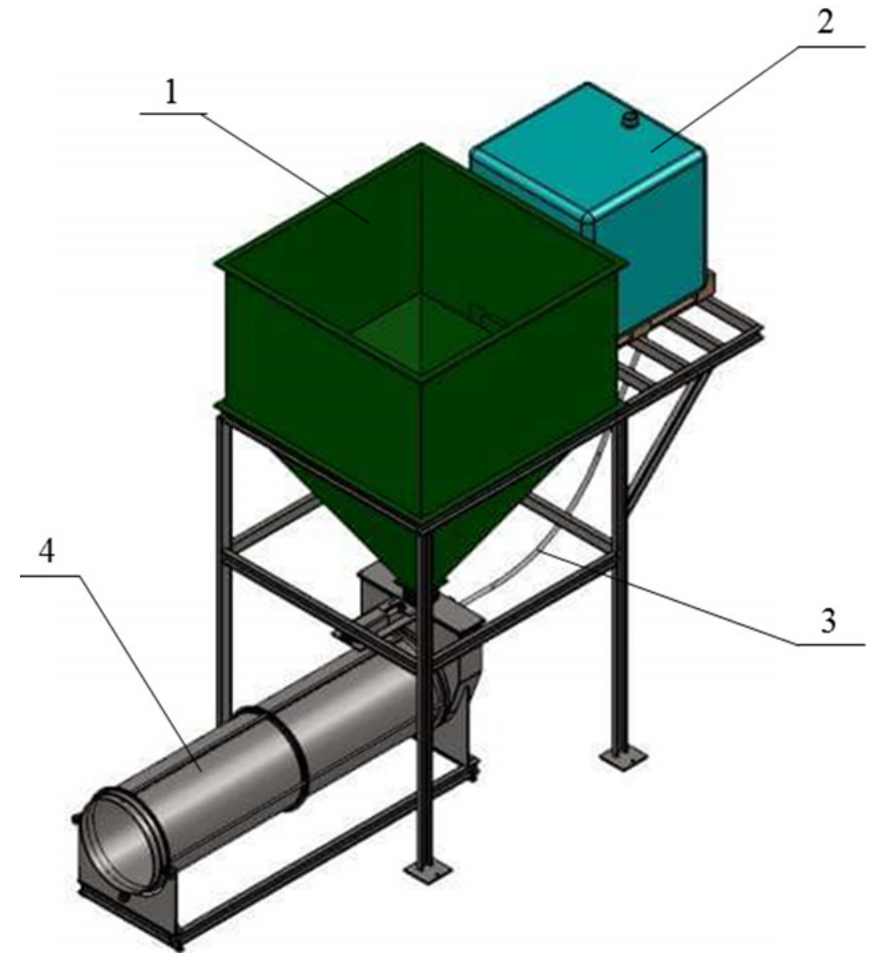

Fig. 1. Ash and slurry mixing equipment: 1 - ash container; 2 - slurry container; 3 - liquid manure supply pipe; 4 - mixer

\section{Results and discussion}

Mixing of ash with water and sapropel was also examined during the study of the ash mixture fraction. The results are summarized in Table 2.

Table 2

Minimal and maximal sizes of granules obtained in the experiments

\begin{tabular}{|c|c|c|c|}
\hline Mixture & Ash ratio to liquid & Length, mm & Width, mm \\
\hline \multirow{3}{*}{ Ash and water } & $1000: 300$ & $2.5-8$ & $2.5-8$ \\
\cline { 2 - 4 } & $1000: 400$ & $2.5-10$ & $2.5-10$ \\
\cline { 2 - 4 } & $1000: 500$ & $3-14$ & $3-20$ \\
\hline \multirow{3}{*}{ Ash and sapropel } & $1000: 300$ & $2.5-12$ & $2.5-12$ \\
\cline { 2 - 4 } & $1000: 400$ & $2.5-18$ & $2.5-18$ \\
\cline { 2 - 4 } & $1000: 500$ & Homogeneous & mass \\
\hline \multirow{3}{*}{ Ash and manure } & $1000: 300$ & $2-5$ & $2-6$ \\
\cline { 2 - 4 } & $1000: 400$ & $2-8$ & $2-8$ \\
\cline { 2 - 4 } & $1000: 500$ & $3-14$ & $3-20$ \\
\hline
\end{tabular}

Evaluating the results of all mixtures, it can be seen that cattle liquid manure should be taken as an ash binder, because the result of the mixture is better in terms of both physical and chemical properties. The ash mixture with water also had good physical properties, but the $\mathrm{pH}$ level is on average two units lower than when mixing ash with slurry (Fig. 2, 3).

On the other hand, mixing ash with sapropel in the plant produces a mud-like mass, which due to its properties sinks the eyes of the mixer drum, but the result obtained while the drum eyes are not sintered is good. (Fig 4, Fig 5). 


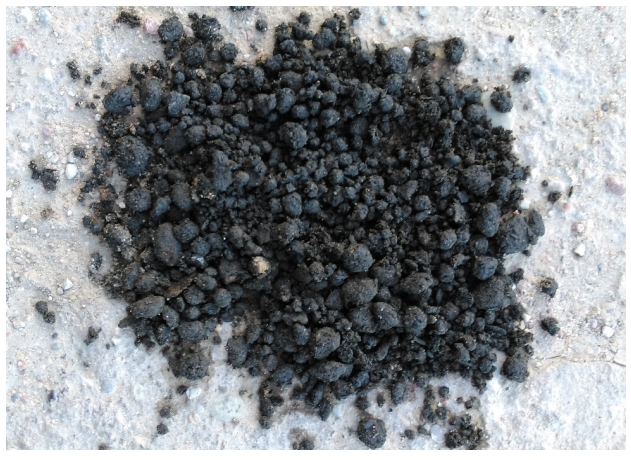

Fig. 2. Ash liquid manure mixture $10: 3$

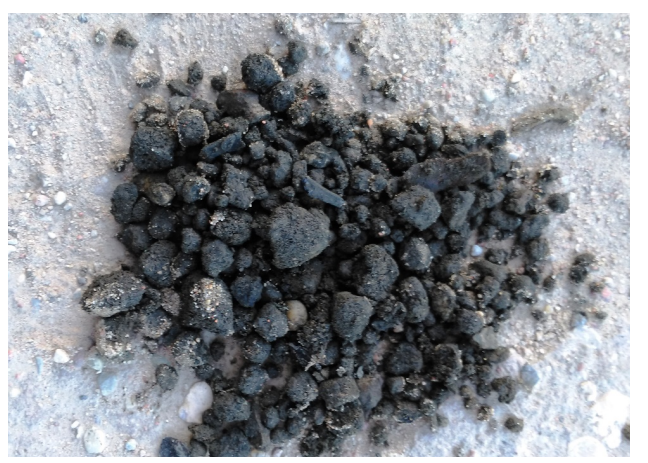

Fig. 4. Ash sapropel mixture $10: 3$

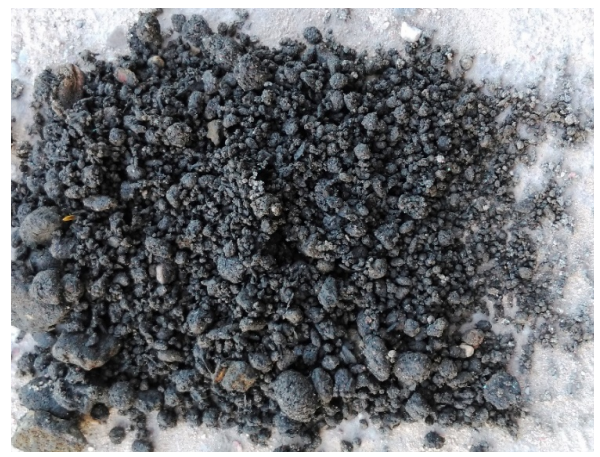

Fig. 3. Ash water mixture 10:3

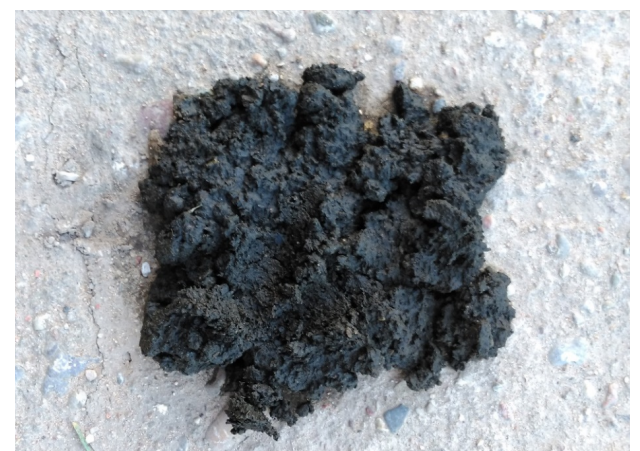

Fig. 5. Ash sapropel mixture $10: 5$

In order to find approximately the required doses of the ash - liquid manure mixture, experiments were performed on the farm "Kaleji K" in 2017 (Fig.6). Fields in which the pH did not exceed 4 were selected for the experiment. Control and plots with doses of 4, 5, 6, 7, 8, 9 and 10 t.ha ${ }^{-1}$ were created for the experiment.

The experimental results show that a field with a soil $\mathrm{pH}$ of 3-4 units requires at least $6 \mathrm{t} \cdot \mathrm{ha}^{-1}$ of ash and slurry mixture. Warts containing up to 20 grains formed in the fields, where this dose was higher. In the fields, where the lower dose of warts was formed, but there were no grains, the control field disappeared when 29 plant development stages were reached (Fig. 7). 450 grains were used per $\mathrm{m}^{2}$.

Large field trials were carried out at the Stende Research Center, using the fertilizers shown in Table 1 (Fig 8 and Fig 9).

The fields to be tested were harvested with a grain harvester Wintersteiger Delta. The harvested grains were cleaned to remove small, damaged grains and impurities. The percentage of pure grains and the weight of 1000 grains are shown in Table 3.

At $13.4 \%$ grain moisture, using equipment Inftatec Nova, qualitative analysis of the grain samples was performed for all 4 fertilization variants. The results are shown in Table 4.

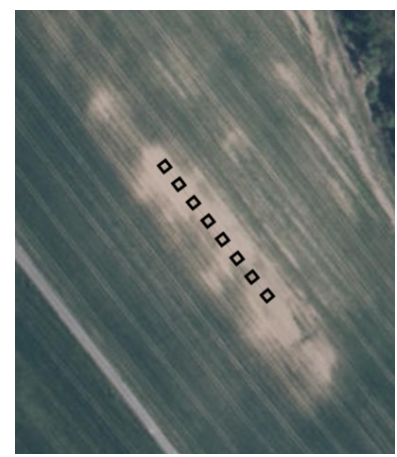

Fig. 6. Scheme of the test field

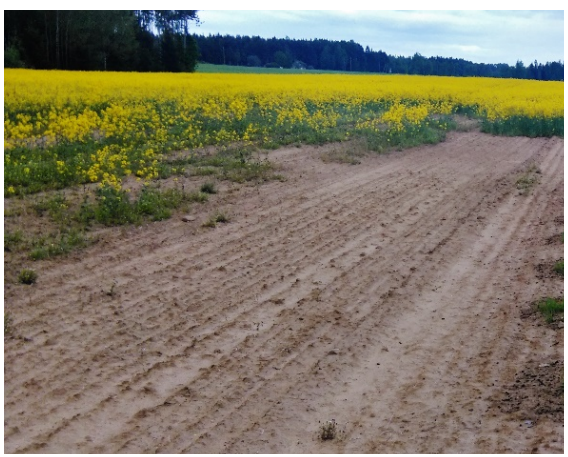

Fig 7. Trial inspection 


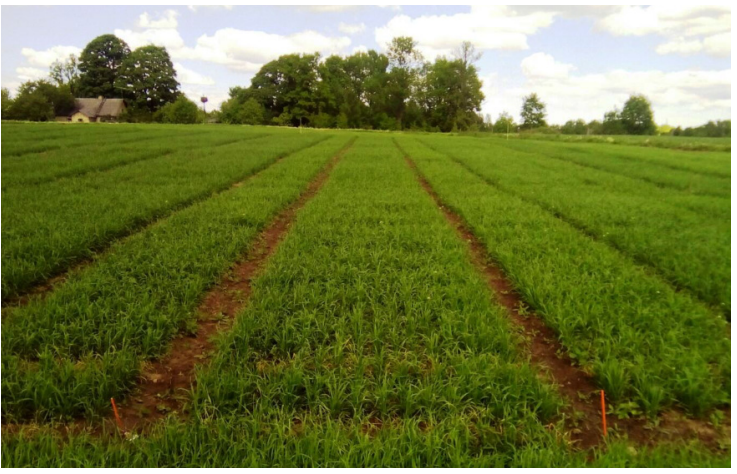

Fig. 8. Test development phase AS 29

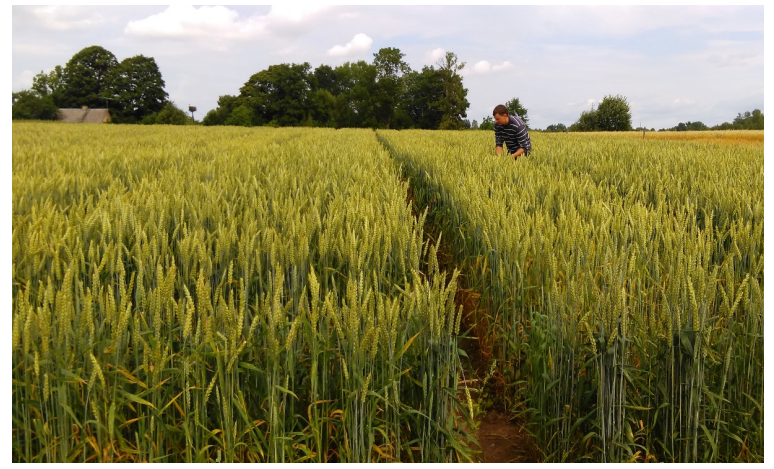

Fig 9. Test development phase AS 59

Table 3

Quantity of pure grains and average weight of 1000 grains

\begin{tabular}{|c|c|c|}
\hline Number of beds & $\begin{array}{c}\text { Percentage of clean grain } \\
\text { after cleaning, \% }\end{array}$ & $\begin{array}{c}\text { Average weight of } \\
\mathbf{1 0 0 0} \text { grains, } \mathbf{g}\end{array}$ \\
\hline A1 & 99.68 & $42.1 \pm 0.8$ \\
\hline A2 & 99.60 & $41.2 \pm 0.3$ \\
\hline A3 & 99.71 & $41.4 \pm 0.3$ \\
\hline A4 & 99.37 & $41.2 \pm 0.6$ \\
\hline
\end{tabular}

After grain cleaning, an increase in the grain weight was observed for wheat fertilized with the ash-liquid manure mixture. Compared to fertilized wheat, it ranged from 10 to $18 \%$, as well as an increase in TGM of 0.4 to $2.6 \%$.

Table 4

Quantity of pure grains and average weight of 1000 grains

\begin{tabular}{|c|c|c|c|}
\hline Number of beds & Protein , \% & Gluten, \% & Starch, \% \\
\hline A1 & 12.1 & 24.0 & 68.9 \\
\hline A2 & 11.5 & 21.7 & 69.4 \\
\hline A3 & 11.6 & 22.2 & 69.4 \\
\hline A4 & 11.9 & 23.1 & 68.9 \\
\hline
\end{tabular}

Changes in the soil $\mathrm{pH}$ during vegetation from April to October were also assessed. Soil samples were taken with a homogeneous soil granulometric composition, the probe at a depth of $20 \mathrm{~cm}$ in 8 places in one bed, mixed in a clean plastic bucket, taken the average. The results are shown in Table 5.

Table 5

\section{Changes in soil acidity}

\begin{tabular}{|c|c|c|c|}
\hline Number of beds & pH (20.04) & pH (20.07) & pH (21.09) \\
\hline A1 & 5.42 & 7.21 & 6.42 \\
\hline A2 & 5.24 & 6.98 & 6.59 \\
\hline A3 & 5.18 & 7.28 & 7.12 \\
\hline A4 & 5.21 & 5.21 & 5.4 \\
\hline
\end{tabular}

The field trials showed that the soil $\mathrm{pH}$ increased by up to 2 units during the first season of application of the mixture.

\section{Conclusions}

1. Biomass ash is suitable for use as a liming and fertilizing material for agricultural land low in phosphorus, potassium and calcium. Granules obtained from a mixture of ash and slurry can compensate for the lack of material in the soil. 
2. The ratio of ash and slurry mixture 10: 3 is the most suitable for spreading the obtained fractions, because their dimensions are similar to the dimensions of mineral fertilizers $2.3-6.0 \mathrm{~mm}$. The resulting mixture can be transported up to $50 \mathrm{~km}$.

3. After grain cleaning, an increase in the grain weight was observed for wheat fertilized with the ash-liquid manure mixture. Compared to fertilized wheat, it ranged from 10 to $18 \%$, as well as an increase in TGM of 0.4 to $2.6 \%$.

4. The field trials confirmed that the soil $\mathrm{pH}$ increased by up to 2 units during the first year of application of the mixture.

\section{References}

[1] Communication on the European Green Deal, European Commission, 2019, [online][11.02.2020] Available at: https://ec.europa.eu/info/publications/communication-european-green-deal_en

[2] Review of waste policy and legislation, European Commission, 2015, [online][11.02.2020] Available at: https://ec.europa.eu/environment/waste/target_review.htm

[3] Etiegni L., Campbell A.G. Physical and chemical characteristics of wood ash. Bioresource Technology 37(2), 1991, pp. 173-178.

[4] Karps O., Aboltins A., Palabinskis J. Biomass ash utilization opportunities in agriculture. Proceedings of the 8th international scientific conference "Rural Development 2017: Bioeconomy Challenges", Kaunas, Lithuania, 2017, pp. 193-198.

[5] Vesterinen P. Wood ash recycling - state of the art in Finland and Sweden. VTT Processes. Research Report, 2003, 52 p.

[6] Vaatainen K., Sirparanta E., Raisanen M., Tahvanainen T. The costs and profitability of using granulated wood ash as a forest fertilizer in drained peatland forests. Biomass and bioenergy 35, 2011, pp. 3335-3341.

[7] Mandre M., Korsjukov R., Ots K. Effect of wood ash on the biomass distribution and physiological state of Norway spruce seedlings on sandy soils. Plant and soil, 265, 2004, pp. 301314.

[8] Mandre M. Influence of wood ash on soil chemical composition and biochemical parameters on young Scots pine, Proc. Estonian Acad. Sci.. Biol. Ecol., 55, 2006, pp. 91-107.

[9] Moilanen M., Silfverberg K., Hokka H., Issakainen J Wood ash as a fertilizer on drained miresgrowth and foliar nutrients of Scots pine. Canadian journal of Forest Research 35(11) 2005, pp. 2734-2742.

[10] Hytonen J., Julha P., Little K. Positive effects of wood ash fertilization and weed control on the growth of Scots pine on former peat- based agricultural land -a 21-year study. Silva Fennica vol. 51(3), 2017, $18 \mathrm{p}$.

[11]Fernández-Pereira C., Casa J.A.,Gómez-Barea A., Arroyo F., Leiva C., Luna Y. Application of biomass gasification fly ash for brick manufacturing. Fuel, Vol. 90, 1, 2011, pp. 220-232.

[12] Garsia M, Sousa-Coutinho J. Strength and durability of cement with forest waste bottom ash Construction and Building Materials Vol. 41, April 2013, pp. 897-910.

[13] Carrasco B. Cruz N., Terrados J., F.A.Corpas F.A., Pérez L. An evaluation of bottom ash from plant biomass as a replacement for cement in building blocks. Fuel, Vol. 118 , 15, 2014, pp. 272280.

[14] Kizinievic O., Kizinievic V. Utilisation of wood ash from biomass for the production of ceramic products. Construction and Building Materials, Vol. 127, 30, 2016, pp. 264-273.

[15] Chowdhury S., Mishra M., Suganya O. The incorporation of wood waste ash as a partial cement replacement material for making structural grade concrete: An overview, Ain Shams Engineering Journal (2014), DOI: 10.1016/j.asej.2014.11.005

[16] Shuiping Y, Qingyao H., Wenhao W., Shefeng L. $\mathrm{CO}_{2}$ absorption using biogas slurry: absorption enhancement induced by biogas ash. Energy Procedia 114, 2017, pp. 890-897.

[17] Asquer C., Cappai G., De Gioannis G., Muntoni A., Piredda M., Spiga D. Biomass ash reutilisation as an additive in the composting process of organic fraction of municipal solid waste. Waste Management, Vol. 69, 2017 .pp. 127-135.

[18] Ozolincius R., Buozyte R., Varnagiryte-Kabasinskiene i. wood ash and nitrogen influence on ground vegetation cover and chemical composition. Biomass and bioenergy 31, 2007, pp.710716. 
[19] Jones, D., Hill, P., \& Chadwick, D. (2017). Critical comparison of the impact of biochar and wood ash on soil organic matter cycling and grassland productivity. Soil Biology and Biochemistry, 110, 2017, pp. 134-142.

[20]Emilson S. International Handbook From Extraction of Forest Fuels to Ash Recycling, Swedish Forest Agency, 2006, 48 p.

[21] Atkinson, C.J., Fitzgerald, J.D., Hipps, N.A., 2010. Potential mechanisms for achieving agricultural benefits from biochar application to temperate soils: a review. Plant and Soil 337, 2010, pp 1-18.

[22] Risse M. Best management practices for wood ash as agricultural soil amendment. UGA Cooperative Extension bulletin 1142. 2013.

[23] Fuzesi I., Heil B., Kovacs G. Effects of wood ash on the chemical properties of soil and crop vitality in small plot experiments Acta Silv. Ling. Hung. vol.11(1) 2015, pp. 55-64.

[24] Pesonen, J., Kuokkanen, T., Rautio, P., Lassi, U. Bioavailability of nutrients and harmful elements in ash fertilizers: Effect of granulation Biomass and Bioenergy Vol.100, 2017, pp. 9297.

[25] Pesonen J., Kuokkanen V., Kuokkanen T., Illikainen M. Co-granulation of bio-ash with sewage sludge and lime for fertilizer use J. of Engineering Chemical Engineering vol. 4 2016, pp. 48174821. 